\title{
Soil microorganisms in the urban ecosystems of the russian subarctic (Murmansk region, Apatity)
}

\author{
Maria V. Korneykova ${ }^{1,2^{*}}$, Vera V. Redkina ${ }^{1}$, Nadezhda V. Fokina ${ }^{1}$, \\ Vladimir A. Myazin ${ }^{1}$, Anastasia S. Soshina ${ }^{1}$ \\ ${ }^{1}$ Institute of North Industrial Ecology Problems - Subdivision of the Federal Research \\ Centre "Kola Science Centre of Russian Academy of Science", 184209, Apatity, \\ Murmansk region, Russia \\ ${ }^{2}$ Peoples' Friendship University of Russia (RUDN University), 6 Miklukho-Maklaya St, \\ Moscow, 117198, Russia
}

\begin{abstract}
A comprehensive study of the quantitative and qualitative parameters of soil microfungi, bacteria and algae communities in the Apatity city, located in the subarctic zone of Russia, was carried out for the first time. Urban soil samples were taken from various landuse zones (residential, recreational) and compared to arable and forest soils. In the residential zone, a decrease in the number of microfungi in the topsoil horizon to 1.1 thous. $\mathrm{CFU} / \mathrm{g}$ compared to 22.7 thous. CFU/g in forest soil was revealed. In the residential zone, an increase was found in the number of saprotrophic bacteria to 7.8 million cells $\mathrm{g}^{-1}$ and oligotrophic to 10.9 million cells $\mathrm{g}^{-1}$ compared to 2.6 million cells $\mathrm{g}^{-1}$ and 1.8 million cells $\mathrm{g}^{-1}$ respectively in forest soils. In the recreational zone, the number of soil microorganisms was similar to that in the forest. A decrease in the species diversity of microfungi in the soil of the residential zone and an increase in the diversity of soil algae were revealed. Among the dominant species of fungi in urban soils, atypical species, including pathogenic ones for humans (Penicillium dierckxii, Stachybotris echinatus, Fusarium sp.), were found. In the algal community, diatoms, yellow-green algae, and cyanobacteria appeared in urban soils in comparison with forest soil. As a result of changes in the quantitative and qualitative indicators of soil microbial communities, a decrease in the enzymatic activity of soils has been noted. This may indicate a weakening of the ecosystem functions of urban soils and an increase in the degree of toxicity for living organisms and humans.
\end{abstract}

Key words: microfungi, bacteria, algae, biodiversity, enzymatic activity

DOI: $10.5817 / \mathrm{CPR} 2021-2-23$

\section{Introduction}

An increase in anthropogenic load and the incidence of the population in recent years has led to increased attention to the study of the urban agglomeration's ecolo-

Received February 17, 2021, accepted October 19, 2021.

${ }^{*}$ Corresponding author: M.V. Korneykova $<$ korneykova.maria@mail.ru>

Acknowledgements: We thank Dr. Andrey Dolgikh (Institute of Geography, RAS) for the valuable help in field work and soil survey and morphological analysis. Field work was supported by state task 1021051803684-1 (FMEZ-2022-0011). Soil microbial analysis was supported by Russian Foundation for Basic Research \# 19-29-05187. Data analysis and processing and paper preparation was supported by Russian Foundation Project \# 17-77-20046. 
gy (Morel et al. 2015, Schmidt 2016, Hui et al. 2017, Huot et al. 2017, Steffan et al. 2018, Vasenev and Kuzyakov 2018). Urbanization has a significant impact on the environment and leads to irreversible changes in the relief, hydrological conditions, vegetation, and soils. The biological properties of urban soils can serve as indicators of their ecosystem functions (Shtina and Gollerbakh 1976, Artamonova 2002, Trukhnitskaya and Chizhevskaya 2008, Sharkova et al. 2011, Gupta et al. 2017, Ivashchenko et al. 2019). The most significant biological characteristics of urban soils are microbial diversity and activity (Schindelbeck et al. 2008, Rozanova et al. 2016). Proportion of various ecological and trophic groups of microorganisms and enzymatic activity of soils are important indicators that directly depend on the characteristics of the microbial community (Schmidt 2016). The evaluation of microorganisms occupying an opposite position in trophic chains (phototrophic - algae and cyanobacteria, and heterotrophic microorganisms - bacteria and microfungi) is also important. It most adequately reflects the ongoing microbiological processes in the soil, characterizing its production and destructive potential(Domracheva et al.2006).

Recently, the methods of molecular genetic analysis have been widely used in the studies of soil microbial communities. However, they do not allow to assess the relative abundance of species (taxa) within rather homogeneous groups of microorganisms with subsequent differentiating accounts of colonies and characteristics of

\section{Material and Methods}

\section{Climate characteristics of the research area}

The Apatity (Murmansk region) is the fifth largest polar city. It is located on the Kola Peninsula beyond the Arctic Circle. The climate is continental, cold and humid (Kottek et al. 2006) with the lowest monthly average temperature (January) of $-13.5^{\circ} \mathrm{C}$ the community structure. In this respect, the traditional methods of culturable microorganisms have not lost their relevance at present, even though no more than $1 \%$ of microorganisms living in natural biotopes are able to grow on nutrient media. Recent plating methods make it possible to evaluate the physiological, biochemical, and morphological characteristics of microorganisms. Therefore, preliminary taxonomic identification can be conducted, as well as the biomass accumulation of certain strains may allow to extract complete genomes for further molecular genetic analysis.

The studies of urban soil microbial community were mainly conducted in areas with a temperate and warm climate, whereas the northern regions remained overlooked (Stepanov et al. 2005, Guilland et al. 2018). Most of the studies were carried out in the USA and China (Han et al. 2011, Reese et al. 2016, Yan et al. 2016, Gill et al. 2017, Wang et al. 2017), Morocco and Poland (Naylo et al. 2019, Beroigui et al. 2020). A similar study was conducted in Finland (Hui et al. 2017). On the Kola Peninsula, soil microorganisms of urban areas were studied only in Murmansk and Kandalaksha (Marfenina et al. 2002, Peretrukhina 2011, Turchanovskaya and Bogdanova 2011). Therefore, we selected Apatity as another location for evaluation of soil microbiota. The purpose of this work is to study the quantitative and qualitative indicators of microorganisms communities (bacteria, microfungi, and algae) in the urban soils of Apatity compared to the forest soils. and a record minimum temperature of $-47^{\circ} \mathrm{C}$ observed in 1985 . The maximum average monthly temperature was detected in July and changed from +10 to $+18^{\circ} \mathrm{C}$. The air temperature in the city is usually 1-2 degrees higher than in the background 
landscapes outside of it (Demin et al. 2016), which can have a decisive impact on the soil biota. The average annual precipitation is $853 \mathrm{~mm}$, with the greatest

\section{Characteristics of site}

The research focused on urban soils in different land use zones (residential and recreational) in comparison to arable and forest soil. The forest soil is a podzol on lake-glacial deposits. The site is located $15 \mathrm{~km}$ from Apatity in the northern taiga amount falling from September to December (about $100 \mathrm{~mm}$ in each of the months) [1]-Weather online;[2]-Climatic data 2020. The prevailing wind direction is northwest.

\begin{tabular}{|c|c|c|c|c|}
\hline Site & Land use zone & $\begin{array}{l}\text { Coordi- } \\
\text { nates }\end{array}$ & $\begin{array}{l}\text { Soil, according } \\
\text { to WRB* }\end{array}$ & Vegetation \\
\hline S-R & Social-recreational & $\begin{array}{l}67.56978 \\
33.40082\end{array}$ & $\begin{array}{l}\text { Umbric Leptic } \\
\text { Entic Podzol } \\
\text { (Arenic, } \\
\text { Technic) }\end{array}$ & $\begin{array}{l}\text { Betula pubescens, Salix } \\
\text { caprea, Populus sp., Poa } \\
\text { pratensis, Festuca rubra, } \\
\text { F. pratensis, Lolium } \\
\text { perenne }\end{array}$ \\
\hline $\mathrm{RZ}-\mathrm{O}$ & $\begin{array}{c}\text { Residential, } \\
\text { external court yard }\end{array}$ & $\begin{array}{l}67.56506 \\
33.41000\end{array}$ & $\begin{array}{l}\text { Umbric Leptic } \\
\text { Entic Podzol } \\
\text { (Arenic, } \\
\text { Technic) }\end{array}$ & $\begin{array}{l}\text { Larix sibirica, Betula } \\
\text { pubescens, Sorbus } \\
\text { gorodkovii, Poa } \\
\text { pratensis, Festuca rubra, } \\
\text { Lolium perenne, } \\
\text { Taraxacum officinale }\end{array}$ \\
\hline RZ-I & $\begin{array}{l}\text { Residential, inner } \\
\text { court yard }\end{array}$ & $\begin{array}{l}67.56139 \\
33.41057\end{array}$ & $\begin{array}{l}\text { Umbric Leptic } \\
\text { Albic Podzol } \\
\text { (Arenic) }\end{array}$ & $\begin{array}{l}\text { Betula pubescens, Salix } \\
\text { caprea, Poa pratensis, } \\
\text { Festuca rubra, F.praten- } \\
\text { sis, Lolium perenne }\end{array}$ \\
\hline AR & Agricultural & $\begin{array}{l}67.57959 \\
33.30014\end{array}$ & $\begin{array}{l}\text { Plaggic Entic } \\
\text { Podzol (Arenic) }\end{array}$ & absent \\
\hline RZ-I-TR & $\begin{array}{c}\text { Residential, inner } \\
\text { court yard, pedes- } \\
\text { trian road (with- } \\
\text { out a hard surface) }\end{array}$ & $\begin{array}{l}67.56139 \\
33.41057\end{array}$ & $\begin{array}{l}\text { Umbric Leptic } \\
\text { Albic Podzol } \\
\text { (Arenic) }\end{array}$ & absent \\
\hline RZ-I-PG & $\begin{array}{l}\text { Residential, inner } \\
\text { court yard, play- } \\
\text { ground (sandy) }\end{array}$ & $\begin{array}{l}67.56139 \\
33.41057\end{array}$ & $\begin{array}{l}\text { Umbric Leptic } \\
\text { Albic Podzol } \\
\text { (Arenic, } \\
\text { Technic) }\end{array}$ & absent \\
\hline FT & $\begin{array}{c}\text { Forest } \\
\text { (background) }\end{array}$ & $\begin{array}{l}67.57885 \\
33.29762\end{array}$ & $\begin{array}{l}\text { Folic Leptic } \\
\text { Albic Podzol } \\
\text { (Arenic) }\end{array}$ & $\begin{array}{l}\text { Pinus friesiana, Picea } \\
\text { obovata, Betula } \\
\text { pubescens, Juniperus } \\
\text { sp., Vaccinium vitis- } \\
\text { idaea, V. myrtillus, } \\
\text { Equisetum arvense }\end{array}$ \\
\hline
\end{tabular}

Table 1. Characteristics of research areas. Note:* WRB - World Reference Base. 


\section{Sampling}

The soil samples were collected from a depth of $0-10 \mathrm{~cm}$ in five replicates in the second decade of June 2019 by the «enve-

\section{Enzymatic activity of soil}

The activity of the hydrolytic enzyme (invertase) and redox enzyme (dehydrogenase) was studied. The invertase activity was determined colorimetrically using the method of Hoffman and Pallauf. The method is based on the ability of glucose and fructose, formed during the hydrolysis of sucrose, to reduce $\mathrm{CuO}$ to $\mathrm{Cu}_{2} \mathrm{O}$ (Hoffman

\section{Microscopic fungi}

The number of colony-forming units (CFU) and the diversity of culturable microfungi were determined by plating methods on Czapek's medium with lactic acid $(4 \mathrm{ml} / \mathrm{l})$ to inhibit bacteria growth (Zvyagintsev 1991). Incubation took place in thermostat at the temperature of $+27^{\circ} \mathrm{C}$ for $7-10$ days and at $+5^{\circ} \mathrm{C}$ for $5-6$ weeks to isolate psychrotolerant strains. The observation of the microfungal diversity was performed based on cultural and morphological features (Olympus CX41 microscope) using keys (Klich 2002, Domsch et al. 2007, Seifert et al. 2011). The species name and systematic position are given

\section{Bacteria}

The saprotrophic bacteria number was determined by plating method on meatpeptone agar, the oligotrophic bacteria number, on the low-mineralized Aristovskaya medium (Hoult et al. 1997). Incuba-

\section{Soil algae and cyanobacteria}

The soil suspension was sown on liquid and agarized nutrient media $3 \mathrm{~N}-\mathrm{BBM}$ and Z8 (Kotai 1972, Gaysina et al. 2008). Algae cultivation took place in light installations equipped with full spectrum phyto- lope» method. Culturable microfungi were identified in fresh samples the day after collection.

and Pallauf 1965, Mineyev et al. 2001). Dehydrogenase activity was determined by a colorimetric method based on the reduction of the colorless salt of 2,3,5triphenyltetrazolium chloride to a red color triphenylformazan (Galstyan 1974, Mineyev et al. 2001).

according to the database: CABI Bioscience Databases ([4]-Index Fungorum 2021). For the sterile mycelium, identification was performed by the analysis of the ITS $1-5.8$ S-ITS2 rDNA region. The DNA was isolated according to the method described by Glushakova et al. (2011). The DNA sections were sequenced using a set of BigDye TerminatorV reagents 3.1 Cycle Sequencing Kit(Applied Biosystems, USA) with subsequent analysis of reaction products on the Applied Biosystems 31301 Genetic Analyzer sequencer at the Syntol Research and Production Center (Moscow).

tion took place in thermostat at the temperature of $+27^{\circ} \mathrm{C}$ for $3-5$ days. Bacteria were identified as a genus based on morphological and cultural characteristics.

lamps (light intensity of $60 \mu \mathrm{mol} \mathrm{m} \mathrm{m}^{-2} \mathrm{~s}^{-1}$ ) at a ratio of light/dark periods of $16 / 8 \mathrm{~h}$ at room temperature. Identification of species was carried out in accumulative and pure cultures obtained by isolation using glass 
capillaries. For the species identification, the conventional keys were used (Andreeva 1998, Ettl and Gärtner 2014, Škaloud et

\section{Statistical analysis}

Mathematical processing of the results was done using standard software packages for statistical calculations (Microsoft Office Excel 2016 and Statistica). The significance of the differences between the

\section{Results and Discussion}

\section{The number of microfungi and bacteria}

It is known that urban soils differ in properties from forest soils and this affects microorganisms (Marfenina et al. 2002, Ivanova et al. 2015, Marfenina and Danilogorskaya 2017). The number of microfungi in the topsoil horizons of the urban soils ranged from $1 \times 10^{3}$ to $9 \times 10^{4} \mathrm{CFU} / \mathrm{g}$ (Table 2). The minimum number was found in the soil of the court yard (RZ-I) and on the pedestrian road in the same court yard (RZ-I-TR), where the soil was maximally compacted. The maximum values were found for the S-R zone soils. The number of microfungi in the forest soil was $2.3 \times 10^{4} \mathrm{CFU} / \mathrm{g}$, which is lower than for the S-R zone, apparently because of the lack of anthropogenic substrates suitable for microfungi uncharacteristic for this forest soil (Marfenina et al. 2002). In general, the forest soils of the northern taiga zone of the Kola Peninsula are characterized by a large number of microfungi, as evidenced by long-term studies (Evdokimova and Mozgova 2001, Korneikova 2018, Korneikova et al. 2018).

Some general trends in the number of culturable microfungi over the urban soil horizons were revealed. In the forest soil, CFU decreased more than 10 times from the topsoil horizon to the subsoil E horizon and then slightly increased to the subsoil Bs horizon. This trend was found earlier for al. 2018). Taxon names were given according to Algaebase ([5]-AlgaeBase 2021).

samples (t) was evaluated using the Student's test; the correlation coefficient (r) was calculated by the square method (Pearson's method) for the significance level of 0.05 .

the distribution of microfungi in the profile of the forest soil (Evdokimova and Mozgova 2001, Korneikova 2018) and is also characteristic of a number of physical and chemical soil properties, which is due to the leaching regime of soils (Zaydelman 2016). In the soil of RZ zone, the maximum number of microfungi was observed in subsoil Bs horizon (RZ-O) and E horizon (RZ-I) which may be due to insufficient oxygen for microfungi resulting from the compaction of the topsoil horizons during trampling (Sherman et al. 2019). In addition, the urban subsoil horizons may contain organic artifacts (Vasenev and $\mathrm{Ku}-$ zyakov 2018), which are an additional substrate for microorganisms. In arable soil (AR), the largest number of microfungi $\left(4.88 \times 10^{3} \mathrm{CFU} / \mathrm{g}\right)$ was observed in the topsoil horizon and then significantly (more than 10 times) decreased in profile. This is probably due to the most active involvement of the topsoil arable horizon in agricultural practices (fertilization, loosening, plowing) and, as a result, numerous breaks in the fungal mycelium by tillage tools, fragments of which give rise to colonies on nutrient media (Trzciński et al. 2018). In the S-R zone soil, a gradual decrease in the number of microfungi was observed in the profile in following order: organic (O) > elluvial (E) > illuvial (Bs). 
This distribution is classical and has been reported by e.g. Polyanskaya and Zvyagintsev (2005), and Vermeire et al. (2019).

The saprotrophic and oligotrophic bacteria number of the urban topsoil horizon exceeded the microorganism's numbers of these trophic groups in the forest soil. The maximum number of heterotrophic bacteria was found in RZ-I-TR soil: 11 million cells $\mathrm{g}^{-1}$ of soil (Fig. 1). The bacteria number in the topsoil horizons of the RZ-I, $\mathrm{RZ}-\mathrm{O}$, and S-R zones ranged from $1.2 \mathrm{mil}-$ lion to 6.7 million cells $\mathrm{g}^{-1}$. In the forest soils, the number of heterotrophic bacteria reached 3.6 million cells $\mathrm{g}^{-1}$, which corresponds to data from earlier studies on microbiological activity in the northern taiga soils of the Kola Peninsula. The highest number of bacteria in urban soils in comparison with forest soils is probably due to younger age of bacterial community, high growth rate of bacteria and rapid "capture" of trophic resources. This is reported in the studies of anthropogenically disturbed urban soils exposed to the influence of human household activities (Artamonova 2002, Lysak 2010, Shumilova and Kuimova 2013). This is especially typical for the soil of the pedestrian road, where a large number of people and animals are present and, accordingly, the additional sources of soil nutrition. In addition, the smallest number of microfungi was found here, as a consequence of the absence of competition for food sources between fungi and bacteria.

Despite their high number, the species diversity of bacteria in all urban soil samples was rather low. Bacteria g. Pseudomonas and Arthrobacter dominated and spore bacteria of the genus Bacillus were less common, which confirm numerous data on the simplification of the microbial communities structure of urban soils, as well as a decrease in the number of bacilli under the influence of deterioration of the sanitary situation (Artamonova 2002).

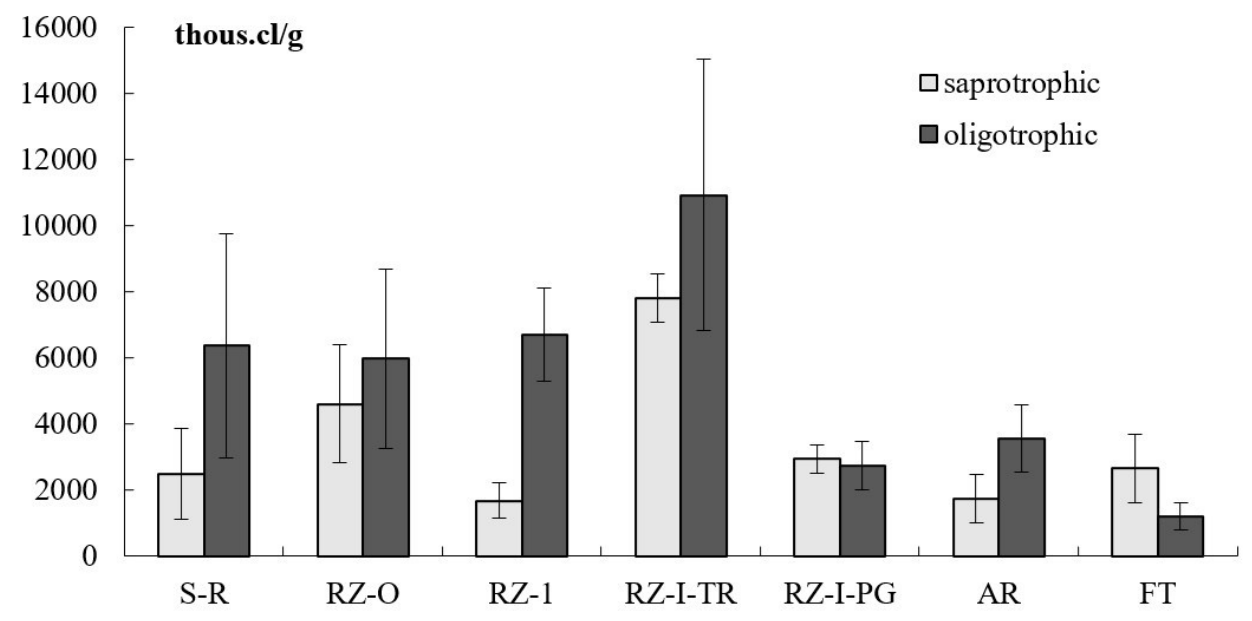

Fig. 1. Number of saprotrophic and oligotrophic bacteria in the topsoil horizon.

The number of saprotrophic and oligotrophic bacteria decreased gradually along the soil profile in both urban and forest soils. In the subsoil horizons, it was an or- der of magnitude lower than in the topsoil horizon (Table 2). However, for the urban subsoil horizons, the second maxima of the bacteria number were revealed (Lysak 
2010). On the whole, the bacteria number varied along the soil profile from 11 thous. to 6 million cells $\mathrm{g}^{-1}$ of soil. In the arable soil, the number of bacteria and microfungi decreased with depth as well.

\section{Diversity of soil microfungi}

The species diversity of soil culturable microfungi was represented by 22 species belonging to 11 genera, 9 families (Aspergillaceae, Ceratocystidaceae, Chaetomiaceae, Hypocreaceae, Mortierellaceae, Nectriaceae, Stachybotryaceae, Torulaceae, Umbelopsidaceae) 7 orders (Eurotiales, Hypocreales, Microascales, Mortierellales, Pleosporales, Sordariales, Umbelopsidales) 5 classes (Dothideomycetes, Eurotiomycetes, Mortierellomycetes, Sordariomycetes, Umbelopsidomycetes) and 2 phyla (Ascomycota, Mucoromycota) (see Fig. 2). The Mucoromycota was represented by the genera Mortierella and Umbelopsis. The Ascomycota division was represented by 8 anamorphic genera (Acremonium, Aspergillus, Berkeleyomyces, Fusarium, Penicillium, Stachybotrys, Torula, Trichocladium). One type of sterile mycelium isolates of uncertain systematic position, has also been identified from complex cultivation.

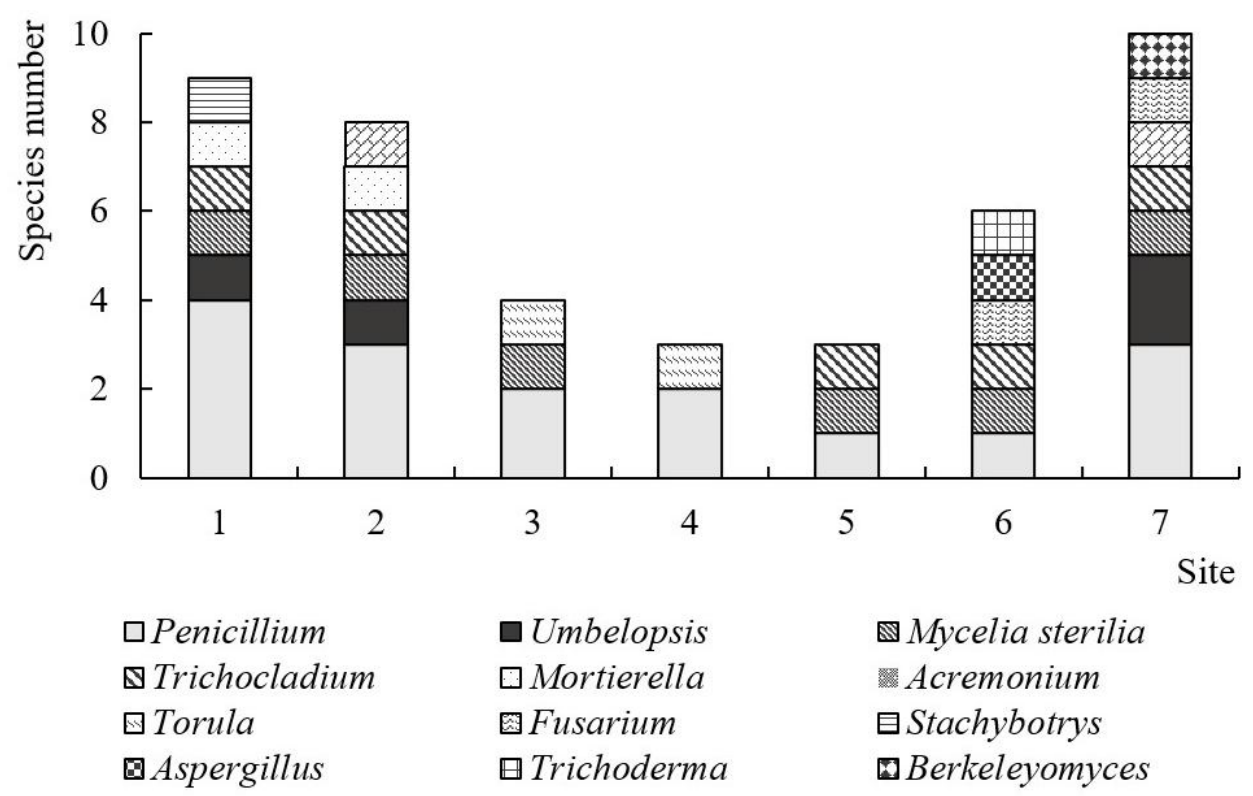

Fig. 2. Diversity of microfungi in the soils. Note: 1 - S-R, 2 - RZ-O, 3 - RZ-I, 4 - RZ-I-TR, 5 -RZ-I-PG, 6 - AR, 7 - FT.

The maximum number of fungal species was isolated from soils of the FT and S-R zones, which may be due to their maximum similarity to the natural biotopes (Ivanova et al. 2015). Both similarities and differences in the species composition of microscopic fungi communities for the soils were found. Thus, Trichocladium griseum, a typical phytopathogen and cellulolytic (Domsch et al. 2007), was isolated 
from the soils of almost all the functional zones studied, except for the court yard soil. Penicillium spinulosum and sterile mycelium were also found in most of the studied soils, while Acremonium felinum, Aspergillus fumigatus, Berkeleyomyces basicola, Penicillium aurantiogriseum, $P$. canescens, $P$. decumbens, $P$. dierckxii, $P$. nalgiovense, Trichoderma koningii and Stachybotrys echinatus were isolated from only one sample under study. The genus Penicillium ( 9 species), whose representatives are typical saprotrophs, was characterized by the greatest species diversity (Domsch et al. 2007, Seifert and Gams 2011) and are often found in the forest soils of the Kola Peninsula (Evdokimova and Mozgova 2001, Marfenina et al. 2002, Korneikova 2018, Korneikova et al. 2018). In urban soils, they also dominated and accounted for $40-70 \%$ of the total number of isolated species. The exception was arable soil, where the proportion of Penicillium was only $16 \%$. The species composition of the soil microfungal complexes is probably greatly influenced by the cultivated plants and their associated microfungal complexes, including pathogenic species, which is also reflected in a number of studies (Carvalhais et al. 2019, Wille et al. 2019, Ye et al. 2020).

The species composition of the urban soil fungal complexes of different land use zones differed significantly from one another, as evidenced by the low values of the Sørensen-Chekanovsky coefficient. The most similar (47\%) were the soils of the S$\mathrm{R}$ and FT zones. The remaining sites were characterized by a specific species composition of microfungal complexes and had a very low degree of similarity with the forest soil.

Urban soils fungal complexes in different land use zones differed in structure of dominant species. The reason for this may be the heterogeneity of urban soils and the presence of specific substrates for microfungi (Marfenina et al. 2017). Fungal com- munity in the RZ zones soils was characterized by monodominant structure, i.e. it had one dominant with a high frequency of occurrence. In the RZ-I soil, the abundance of $P$. dierckxii was $82 \%$, and in the RZ-I-PG soil, the abundance of P. melinii was $85 \%$. Representatives of the genus Penicillium often dominate in abundance in the soils of the northern regions (Domsch et al. 2007).

Soils of FT and S-R zones were characterized by polydominant structure complexes of microscopic fungi. In the S-R zone, Penicillium melinii, P. simplicissimum, and Stachybotrys echinatus prevailed, while $P$. decumbens, $P$. melinii, and Umbelopsis isabellina predominated in the FT zone. The polydominant structure of microfungal complexes was also characteristic of arable soil. The abundance of the predominant species was $43 \%$ (Fusarium sp.), 29\% (Trichocladium griseum), and $21 \%$ (P. miczynskii).

Comparing the composition of the dominant species in forest and urban soils, the appearance of atypical species in the city was noted. For example, the species Trichocladium griseum was previously found in the soils of the region but belonged to the group of random and rare species. Microfungi of the genus Fusarium, which dominate in arable soil, are also not characteristic of the soils of the Kola Peninsula. As is known, species of this genus are often parasites on cultivated and forage plants (Domsch et al. 2007). This probably explains their large number in arable soil. The dominance of dark-pigmented microfungi in urban soils also attracts attention. It is known that pigmentation of organisms is a protective function against negative effects (Nosanchuk et al. 2015, Marfenina et al. 2017), and at the same time, most of the melanized microfungi belong to the group of opportunistic pathogens for humans (Marfenina and Danilogorskaya 2017). 


\section{Diversity of soil algae and cyanobacteria}

In the urban soils, peculiar communities of algae and cyanobacteria are formed, which differ in taxonomic composition, the complex of dominant species, ecological structure, as well as in abundance and biomass (Shtina 1990, Artamonova 2002, Sharipova and Dubovik 2004, Aksenova and Baranova 2010, Khaybullina et al. 2011, Bachura and Blagodatnova 2015, Dorokhova et al. 2015, Maltsev et al. 2017).

In the studied soils, 50 species of algae and cyanobacteria were found belonging to 3 divisions: Chlorophyta (classes Chlorophyceae, Trebouxiophyceae, Ulvophyceae) - 36 species, Ochrophyta (classes Bacillariophyceae, Xanthophyceae) 10 species, Cyanobacteria - 4 species. At the same time, there was a significant increase in the diversity of algae in urban soils (49 species versus 6 in forest soil), which is associated with the emergence of new ecological niches and is generally quite typical for places with relatively poor and fairly homogeneous floristic composition of algal groups, for example, for the taiga zone (Kabirov 1991). The difference in habitat conditions explains the low degree of similarity in the species composition of microphototrophic communities in the surveyed areas - the SørensenChekanovsky coefficient does not exceed $25 \%$. The maximum diversity was found in the soil of the S-R zone (19 species), as well as in the substrate from the pedestrian road (RZ-I-TR) (20 species). The increase in species diversity was explained by the effect of "intermediate disturbance", in which the maximum diversity is preserved at the average intensity of the impact of disturbing factors (Odum 1986, Shea et al. 2004). The smallest number of species (only 5) was found in the soil of the RZ-I zone (Fig. 3). At the same time, this site does not differ from others by the abnormal level of soil contamination. According to our assumptions, the low species diversity here is due to the strong shading of the court yard.

A change in the structure of soil algae communities in urban soils compared to forest soils was revealed. The forest was characterized by absolute dominance of green algae, including genera Elliptochloris, Neocystis, Pseudococcomyxa, Stichococcus, etc. At the same time, the predominance of algae from the division Chlorophyta was found. Their low diversity is often characteristic for northern podzolic soils under tundra and forest vegetation (Evdokimova and Mozgova 2001, Korneykova et. al. 2017). In the soils of the RZ zone, algae from the Chlorophyta division reached $74-82 \%$, while in arable soil, on the playground and on the pedestrian road, their share decreased to $54-60 \%$. Changes in the community's structure occur due to the appearance and growth of the diversity of diatoms, yellowgreen algae (Botrydiopsis, Xanthonema) and cyanobacteria (Fig. 3). Previously, we found a noticeable diversity within these groups in fouling on the surface of technogenic substrates (Redkina et al. 2020, Davydov and Redkina 2021), as well as in disturbed soils near the Kandalaksha aluminum plant (Redkina et al. 2020). It should be noted that the degree of development of yellow-green algae is an indirect indicator of the soil "purity". When the substrate is heavily contaminated, representatives of this division are the first to "drop out" from the algal community (Shtina 1990). Micrographs of some algae species found in urban soils were shown in Fig. 4. 
M. V. KORNEYKOVA et al.

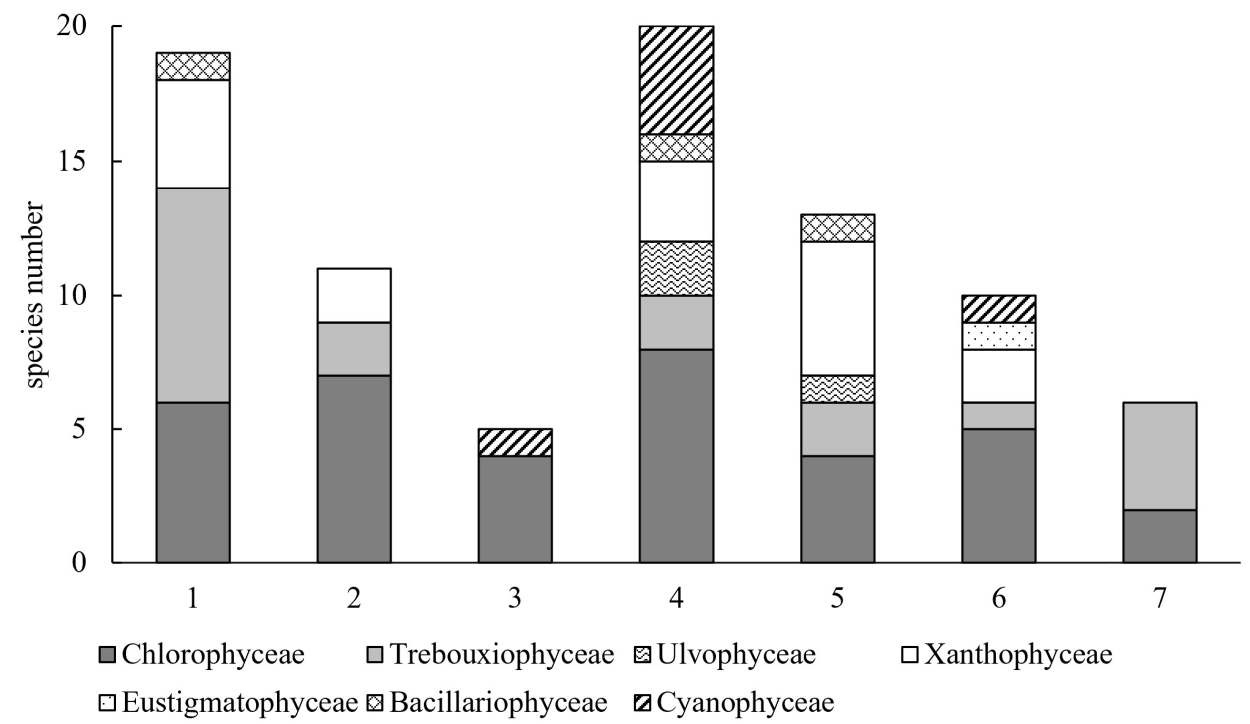

Fig. 3. Taxonomic structure of cyanobacterial and algal communities in the soils. Note: $1-\mathrm{S}-\mathrm{R}$, 2 - RZ-O, 3 - RZ-I, 4 - RZ-I-TR, 5 -RZ-I-PG, 6 - AR, 7 - FT.
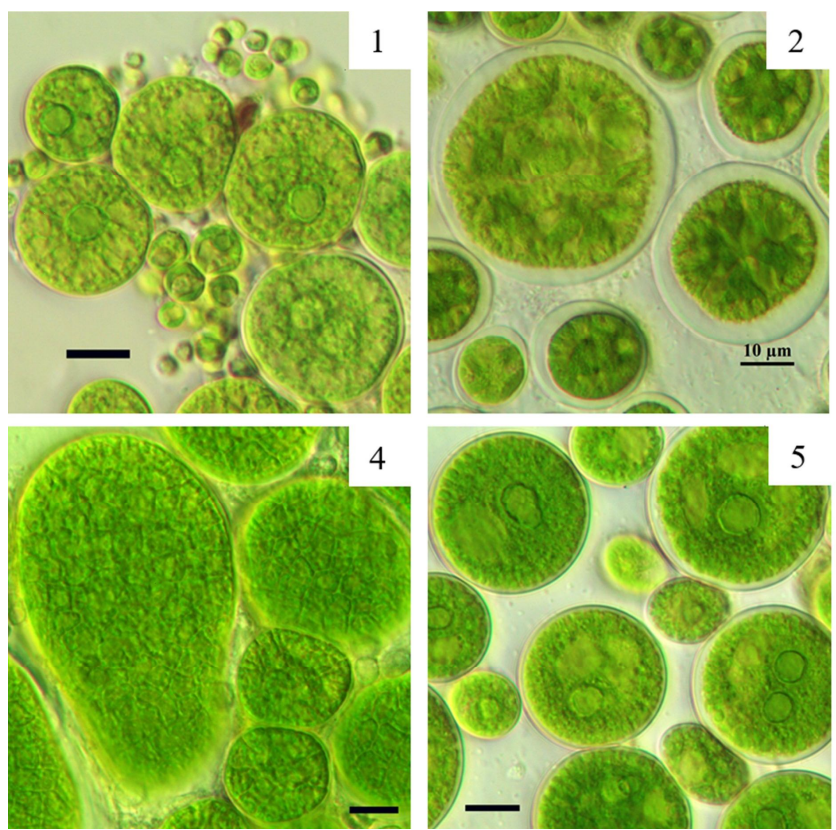

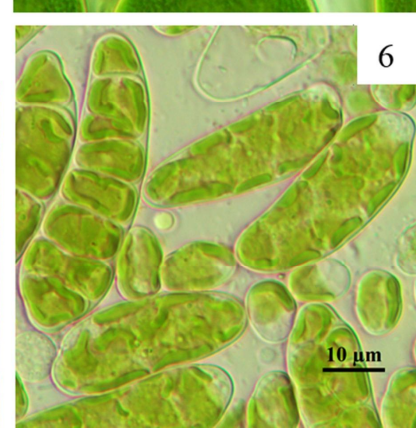

Fig. 4. Micrographs of some algae species. 1 - Neospongiococcum cf. commatiforme, 2 - Actinochloristerrestris, 3 - Pseudodictyochlorisdissecta, 4 - Dictyococcusvarians, 5 -Macrochlorismultinucleate, 6 - Bumilleriopsisfiliformis. 


\section{Enzymatic activity of soil}

The enzymatic activity is one of the indicators of the soil's biological activity, which characterizes the processes taking place in it. The study of invertase activity is of great interest because this enzyme is involved in carbohydrate metabolism in the soil, carrying out the hydrolytic degradation of incoming organic matter in the process of humus formation. Dehydrogenases catalyze the dehydrogenation reactions of organic substances (carbohydrates, organic acids, alcohols, humic acids, etc.) and act as intermediate hydrogen carriers. In the soil, dehydrogenases of carbohydrates and organic acids are active. Dehydrogenase activity is an indicator of the vital activity of microorganisms and the amount of degradable humic substances.

Decrease in the enzymatic activity in the urban topsoil horizons was apparent in comparison with the FT soils (Table 2). This trend was also reported for the more southern regions: the urbanized territories of Azerbaijan (Kazimov and Ali 2012), Rostov-on-Don, and Azov (Baranova et al. 2010). However, in the soil of the court yard (R-Z), the invertase activity was comparable to that in the FT soil, while the dehydrogenase activity was higher. The enzyme activity in the soil of the S-R zone is 2.5 times lower than in the FT zone, but at the same time, it is 2 times higher than in the AR zone. Some data show that the enzymatic activity of soils in S-R areas is close to that in natural soils (Zabelina 2014). It may indicate a significant potential for soil self-purification as shown by Trifonova and Zabelina (2017). The minimum value of enzymatic activity was found in AR soil, probably due to a low input of organic carbon with plant litter, a low number of microorganisms, and the lowest $\mathrm{pH}$ value of all the studied soils.

The highest activity of the studied en- zymes was observed on the pedestrian road. In the same sample, the maximum number of bacteria was observed. This is probably due to the increased load from pedestrian and animal foot traffic, etc. From an ecological perspective, these results can be considered an adaptive response of the soil to anthropogenic loads, neutralization of pollution and self-cleaning of the soil (Trifonova and Zabelina 2017).

It is known that enzymes enter the soil because of the activity of microorganisms, with root secretions, from decaying animal and plant remain (Mishustin and Shilnikova 1968, Khaziyev 1972, 1976). In different urban functional zones, different groups of microorganisms can have a decisive influence on the enzymatic activity. In the S-R, AR, and FT zones, a strong positive correlation $(r=0.97-1.00)$ was established between the activity of enzymes and the number of microorganisms in both groups (bacteria and microfungi), whereas in the soil of the RZ zone, the activity of enzymes demonstrates the greatest correlation with the number of bacteria $(\mathrm{r}=0.96$ 0.99).

Enzymatic activity in urban and forest soils decreased along the soil profile from the topsoil horizons to the lower. In FT soils, the distribution of enzymes along the soil profile corresponded to the distribution of the microorganisms: a decrease in activity in the subsoil $\mathrm{E}$ horizon, then a slight increase in the subsoil Bs horizon. The same trend was found for the soil of the court yard of the RZ zone. In this case, the vertical distribution of enzyme activity was due to the structure of the soil profile: there was an E horizon, where organic matter accumulates. In the soils of the other functional zones, the enzyme activity decreased evenly down the soil profile. 


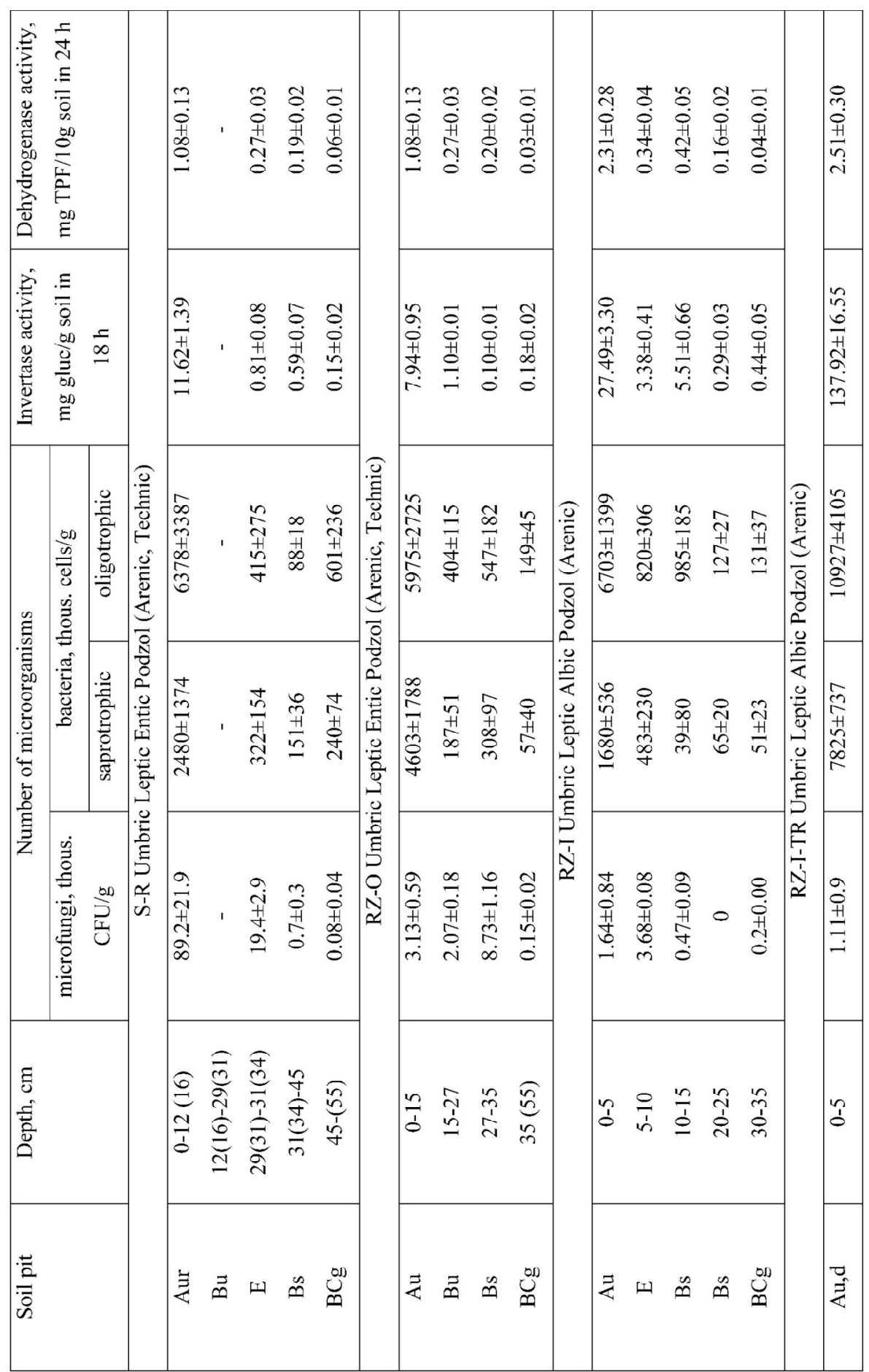




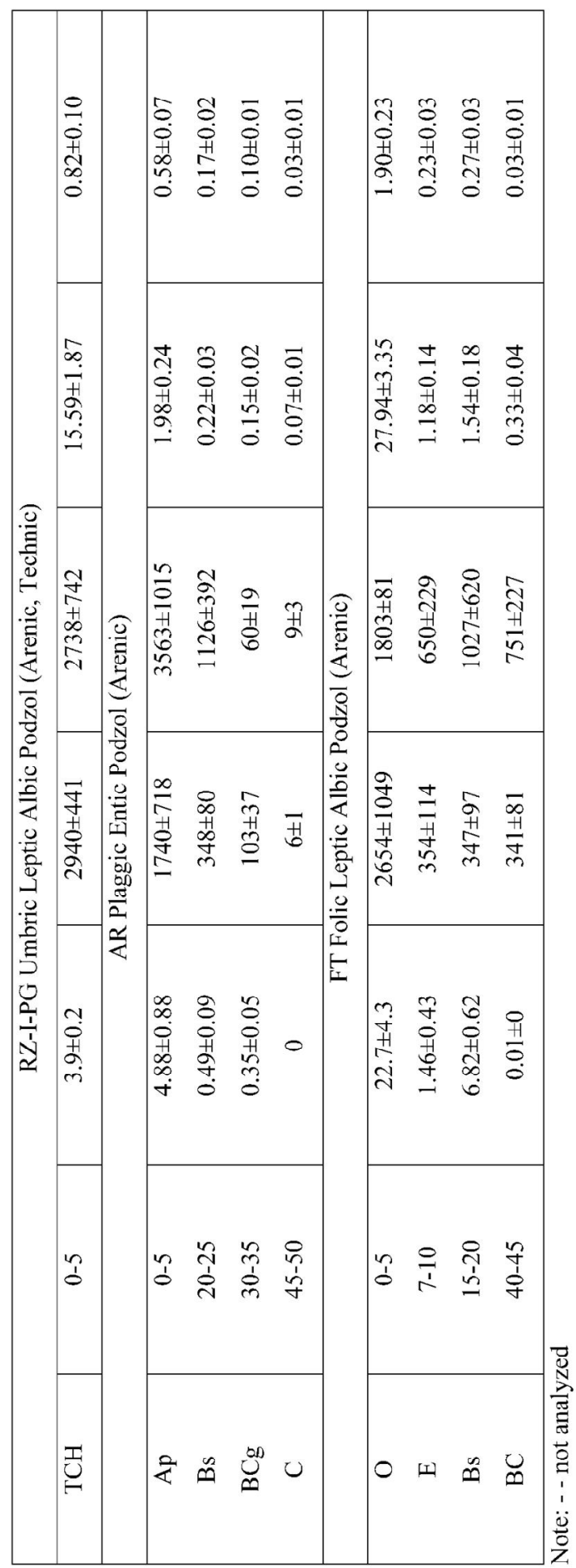

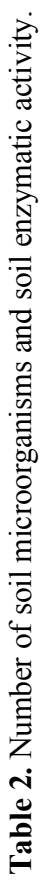




\section{Conclusion}

Significant differences in the quantitative and qualitative parameters of the culturable microorganism's communities (bacteria, microfungi, algae) in urban soils in the subarctic zone compared with the forest soils were revealed. According to the indicators used in this study (number of microfungi, bacteria, soil enzymatic activity, species diversity of microfungi and algae), the soil microorganisms communities in the S-R zone were the most similar to FT zone, which may be due to a lower level of anthropogenic load on this territory. Soils of RZ zones revealed a marked decrease in the fungi number, with some growth in the oligotrophic bacteria number; the decrease of enzymatic activity was observed only in the soil of the RZ-O, near the road. In the substrate of a pedestrian road without a hard surface, a sharp increase in the heterotrophic bacteria number and a growth in the enzymatic activity, especially invertase, were recorded with a significant decrease in the microfungi number. The algae and cyanobacteria communities in this area were characterized by maximum diversity. The increased load on this site from humans and animals probably contributes significantly to the state of the microbial communities (Sherman et al. 2019).

Some trends in the microorganism's distribution in the soil profile were revealed. In the urban soils of the RZ zone, the greatest number of fungi was found in the subsoil horizons, while in the FT - in the topsoil horizon. The bacteria number was always highest in the topsoil horizons and decreased quite evenly down the profile.

In total, 22 species of microscopic fungi and 50 species of soil algae were found in the urban soils. There was a decrease in the diversity of culturable microfungi and bacteria with an increase in the microalgae diversity in urban soils compared with FT soils. In urban areas, the dominance type of microfungal communities' changes to monodominant, whereas FT soil was characterized by a polydominant structure. In the composition of microalgae, the appearance of groups atypical for the background soils of the region was witnessed: diatoms, yellow-green algae, and cyanobacteria.

\section{References}

Aksenova, N. P., Baranova, O. G. (2010): Short observe of soil cyanoprocaryotes and algae coenoses biodiversity at the Izhevsk city. Vestnik Udmurskogo universiteta. Seriya "Biologiya. Nauki o Zemle" [Bulletin of the Udmurt University. Series "Biology. Earth Sciences"], 1: 27-31. (In Russian).

AnDReEva, V. M. (1998): Soil and aerophilic green algae. Nauka Publ., Moscow, Russia, 348 p. (In Russian).

ARTAMONOVA, V. S. (2002): Microbiology of anthropogenically transformed soils of Western Siberia. SO RAN Publ., Novosibirsk, Russia, 225 p. (In Russian).

Bachura, Yu. M., Blagodatnova, A. G. (2015): Phytocenological group structure of soil algae and cyanobacteria of urban lawn (on the example of Novosibirsk and Gomel). Vestnik Novosibirskogo gosudarstvennogo pedagogicheskogo universiteta [Bulletin of the Novosibirsk State Pedagogical University], 5(3): 82-93. (In Russian). doi: 10.15293/2226-3365.1503.08

Baranova, E. V., Ilyshkina, L. N. and Polyakova, A.V. (2010): The change of enzymatic activity of soils under city conditions. Antropogennaya transformatsiya prirodnoy sredy [Anthropogenic transformation of the natural environment], 1: 144-149. (In Russian).

Beroigui, M., Naylo, A., WalczaK, M., Hafidi, M., CharzyŃSki, P., ŚWitoniaK, M., RÓżański, S. and Boularbah, A. (2020): Physicochemical and microbial properties of urban park soils of 
the cities of Marrakech, Morocco and Toruń, Poland: Human health risk assessment of fecal coliforms and trace elements. Catena, 194: 104673. doi: 10.1016/j.catena.2020.104673

Carvalhais, L. C., Rincon-Florez, V. A., Brewer, P. B., Beveridge, C. A., Dennis, P. G. and SCHENK, P. M. (2019): The ability of plants to produce strigolactones affects rhizosphere community composition of fungi but not bacteria. Rhizosphere, 9: 18-26. doi: 10.1016/j.rhisph. 2018.10.002

DAVYDOV, D. A., ReDKINA, V. V. (2021): Algae and cyanoprokaryotes on naturally overgrowing ash dumps of the Apatity Thermal Power Station (Murmansk region). Seriya Biogeografiya [Biogeography Series], 1: 51-68. (In Russian). doi: 10.17076/bg1270

Demin, V. I., Kozelov, B. V., Yelizarova, N. I. and Menshov, Yu. V. (2016): Geomorphological factors of the formation of the "heat island" in Apatity. Physics of Auroral Phenomena, 39(1): 154-157. (In Russian).

Domracheva, L. I., Dabakh, E. V., Kondakova, L. V. and Varaksina, A. I. (2006): Algalmycological complexes in soils upon their chemical pollution. Eurasian Soil Science, 39: 591597. doi: 10.1134/S1064229306130151

Domsch, K.H., GAMS, W. and ANDERSON, T. H. (2007): Compendium of soil fungi. $2^{\text {nd }}$ ed. IHW Verlag, Ehing, Germany, 672 p.

Dorokhova, M. F., Kosheleva, N. E. and Terskaya, E. V. (2015): Algae and cyanobacteria in soils of Moscow. American Journal of Plant Sciences, 6(15): 2461-2471. doi: 10.4236/ajps. 2015.615248

EtTl, H., GÄRTner, G. (2014): Syllabus of soil, air and lichens algae. 2., ergänzte Auflage. Springer, Berlin, Heidelberg, 773 p. (In German). doi: 10.1007/978-3-642-39462-1

Evdokimova, G. A., Mozgova, N. P. (2001): Microorganisms of tundra and forest podzols of the Kola North. KSC RAS Publ., Apatity, Russia, 184 p. (In Russian).

Galstyan, A. Sh. (1974): Enzymatic activity of soils in Armenia. Aiastan Publ., Yerevan, Armenia, 274 p. (In Russian).

GAYsina, L. A., FAZlutdinOvA, A. I. and Kabirov, R .R. (2008): Modern methods of isolation and cultivation of algae. Tutorial. Bashkir State Pedagogical University Publ., Ufa, Russia, 152 p. (In Russian).

Gill, A. S., Lee, A. and McGuire, K. L. (2017): Phylogenetic and functional diversity of total (DNA) and expressed (RNA) bacterial communities in urban green infrastructure bioswale soils. Applied and Environmental Microbiology, 83(16): e00287-17. doi: 10.1128/ AEM.00287-17

Glushakova, A. M., Kachalkin, A. V. and Chernov, I. Y. (2011): Specific features of the dynamics of epiphytic and soil yeast communities in the thickets of Indian balsam on mucky gley soil. Eurasian Soil Science, 44 (8): 886-892. doi: 10.1134/S1064229311080059

Guilland, C., Maron, P. A., Damas, O. and RANJARD, L. (2018): Biodiversity of urban soils for sustainable cities. Environmental Chemistry Letters, 16(4): 1267-1282. doi: 10.1007/s10311018-0751-6

Gupta, S., Kumar, M., Kumar, J., Ahmad, V., Pandey, R. and Chauhan, N. S. (2017): Systemic analysis of soil microbiome deciphers anthropogenic influence on soil ecology and ecosystem functioning. International Journal of Environmental Science and Technology, 14(10): 22292238. doi: 10.1007/s13762-017-1301-7

Han, X., Wang, R., Guo, W., Pang, X., Zhou, J., Wang, Q., Zhan, J. and DaI, J. (2011): Soil microbial community response to land use and various soil elements in a city landscape of north China. African Journal of Biotechnology, 10(73): 16554-16565. doi: 10.5897/AJB10. 1682

Hoffmann, G., Pallauf, J. (1965): A colorimetric method to determine the sucrose activity of soils. Zeitschrift für Pflanzenernährung, Düngung, Bodenkunde [Journal of Plant Nutrition, Fertilization, Soil Science], 110(3): 193-201. (In German). doi: 10.1002/jpln. 19651100304

Hoult, J., Krieg, N., Snit, P., Staley, J. and Williams, S. (1997): Bergey's guide to bacteria. Mir, Moscow, Russia, 432 p. 
Hui, N., Jumpronen, A., Francini, G., Kotze, D.J., Liu, X., Romantschul, M., Srömmer, R. and SETAL, H. (2017): Soil microbial communities are shaped by vegetation type and park age in cities under cold climate. Environmental Microbiology, 19(3): 1281-1295. doi: 10.1111/14622920.13660

Huot, H., Joyner, J., Córdoba, A., Shaw, R. K., Wilson, M. A., Walker, R., Muth, T. R. and CHENG, Z. (2017): Characterizing urban soils in New York City: Profile properties and bacterial communities. Journal of Soils and Sediments, 17(2): 393-407. doi: 10.1007/s11368-016-1552-9

Ivanova, A. E., Nikolaeva, V. V. and Marfenina, O. E. (2015): Changes in the cellulolytic activity of urban soils induced by the removal of plant litter (using Moscow as an example). Eurasian Soil Science, 48(5): 501-508. doi: 10.1134/S1064229315030059

Ivashchenko, K., Ananyeva, N., Vasenev, V., Sushro, S., Seleznyova, A. and Kudeyarov, V. (2019): Microbial C-availability and organic matter decomposition in urban soils of megapolis depend on functional zoning. Soil \& Environment, 38(1): 31-41. doi: 10.25252/ SE/19/61524

KABIROV, R. R. (1991): Soil algae of technogenic landscapes. Extended abstract of Doctor of Sciences (Biol) Dissertation, St. Petersburg, 35 p. (In Russian).

Kazimov, M. A., Ali, F. M. (2012): The hygienic importance of the research of enzymatic activity of soils from roadside territories. Sibirskiy meditsinskiy zhurnal [Siberian Medical Journal], 110(3): 118-122. (In Russian).

Khaybullina, L. S., Sukhanova, N. V. and Kabirov, R. R. (2011): Flora and Syntaxonomy of Soil Algae and Cyanobacteria in Urbanized Areas. Gilem Publ., Ufa, Russia, 216 p. (In Russian).

KhaziYev, F. KH. (1972): Soil enzymes. Znaniya Publ., Moscow, Russia, 257 p. (In Russian).

KhaZIYev, F. KH. (1976): Enzymatic activity of soils. Nauka Publ., Moscow, Russia, 179 p. (In Russian).

KLICH, M.A. (2002): Identification of common Aspergillus species. CBS Fungal Biodiversity Centre, Utrecht, Netherlands, $116 \mathrm{p}$.

KORNEIKOVA, M. V. (2018): Comparative analysis of the number and structure of the complexes of microscopic fungi in tundra and taiga soils in the north of the Kola Peninsula. Eurasian Soil Science, 51(1): 89-95. doi: 10.1134/S1064229318010106

Korneikova, M. V., Redkina, V. V. and Shalygina, R. R. (2018): Algological and mycological characterization of soils under pine and birch forests in the Pasvik Reserve. Eurasian Soil Science, 51(2): 211-220. doi: 10.1134/S1064229318020047

Korneykova, M., RedkinA, V. and Shalygina, R. (2017): Algae, cyanobacteria, and microscopic fungi complexes in the Rybachy Peninsula soils, Russia. Czech Polar Reports, 7(2): 181-194. doi: $10.5817 /$ CPR2017-2-18

KотAI, J. (1972): Instructions for preparation of modified nutrient solution Z8 for algae. Norwegian Institute for Water research, Oslo, Norway, B-11/69, 5 p.

Kottek, M., Grieser, J., Beck, C., Rudolf, B. and Rubel, F. (2006): World Map of the KöppenGeiger climate classification updated. Meteorologische Zeitschrift [Meteorological journal], 15(3): 259-265. doi: 10.1127/0941-2948/2006/0130

LYSAK, L.V. (2010): Bacterial communities of urban soils. Extended abstract of Doctor of Sciences (Biol) Dissertation, Moscow, 48 p. (In Russian).

Maltsev, Y. I., Pakhomov, A. Y. and Maltseva, I. A. (2017): Specific features of algal communities in forest litter of forest biogeocenoses of the steppe zone. Contemporary Problems of Ecology, 10: 71-76. doi: 10.1134/S1995425517010085

Marfenina, O. E., Danilogorskaya, A. A. (2017): Effect of elevated temperatures on composition and diversity of microfungal communities in natural and urban boreal soils, with emphasis on potentially pathogenic species. Pedobiologia, 60: 11-19. doi: 10.1016/j.pedobi. 2016.11.002

MarfeninA, O. E., Kul'Ko, A. B., Ivanova, A. E. and Sogonov, M. V. (2002): The microfungal communities in the urban outdoor environment. Mikologiya i Fitopatologiya [Mycology and phytopathology], 36(4): 22-32 (In Russian). 
Marfenina, O. E., Lysak, L. V., Ivanova, A. E., Glushakova, A. M., Kachalkin, A. V., Nikolaeva, V. V., Karlsen, A. A. and Tepeeva, A. N. (2017): Biodiversity in urban soils: threats and opportunities (on the example of cultivated microorganisms). In: Abstract book of $9^{\text {th }}$ international congress Soils of Urban Industrial Traffic Mining and Military Areas. "Urbanization: A challenge and an opportunity for soil functions and ecosystem services", 22-26 May 2017, Moscow, Russia, pp. 337-339

Mineyev, V. G., Sychev, V. G., Amelyanchik, O. A., Bolysheva, T. N., Gomonova, N. F., Durynina, Ye. P., Yegorov, B. C., Yegorova, Ye. V., Yedemskaya, N. L., Karpova, Ye. A. and Prizhukova, V. G. (2001): Practical manual on agrochemistry. Moscow State University Publ., Moscow, Russia, 689 p. (In Russian).

Mishustin, Ye. N., Shilnikova, V. K. (1968): Biotic fixation of atmospheric nitrogen. Nauka Publ., Moscow, Russia, 531 p. (In Russian).

Morel, J. L., Chenu, C. and LoREnz, K. (2015): Ecosystems services provided by soil of urban, industrial, traffic, mining, and military areas (SUITMAs). Journal of Soils and Sediments, 15: 1659-1666. doi: 10.1007/s11368-014-0926-0

Naylo, A., Pereira, S. I. A., Benidire, L., Khalil, H. E., Castro, P. M. L., Ouvrard, S., Schwartz, C. and Boularbah, A. (2019): Trace and major element contents, microbial communities, and enzymatic activities of urban soils of Marrakech city along an anthropization gradient. Journal of Soils and Sediments, 19(5): 2153-2165. doi: 10.1007/s11368-018-2221-y

Nosanchuk, J. D., Stark, R.E. and Casadevall, A. (2015): Fungal melanin: what do we know about structure? Frontiers in Microbiology, 6: 1463. doi: 10.3389/fmicb.2015.01463

Odum, Yu. (1986): Ecology. In 2 vols. Mir Publ., Moscow, Russia, Vol. 1. 328 p., Vol. 2. 376 p. (In Russian).

PeretrukhinA, A. T. (2011): Sanitary and microbiological studies of soils in Murmansk city and the Murmansk region. Mezhdunarodnyy zhurnal eksperimentalnogo obrazovaniya [International Journal of Experimental Education], 6: 14-16. (In Russian).

Polyanskaya, L. M., ZvyaginTSEv, D. G. (2005): The content and composition of microbial biomass as an index of the ecological status of soil. Eurasian Soil Science, 38(6): 625-633.

Redkina, V. V., Korneykova, M. V. and Shalygina, R. R. (2020): Microorganisms of the Technogenic Landscapes: The Case of Nepheline-Containing Sands, the Murmansk Region. In: O. Frank-Kamenetskaya, D. Vlasov, E. Panova, S. Lessovaia (eds.): Processes and Phenomena on the Boundary Between Biogenic and Abiogenic Nature. Lecture Notes in Earth System Sciences. Springer, Cham, pp. 561-579. doi: 10.1007/978-3-030-21614-6_30

Reese, A. T., Savage. A., Youngsteadt, E., McGuire, K. L., Koling, A., Watkins, O., Frank, S. D. and DunN, R. R. (2016): Urban stress is associated with variation in microbial species composition-but not richness-in Manhattan. Multidisciplinary Journal of Microbial Ecology, 10(3): 751-760. doi: 10.1038/ismej.2015.152

Rozanova, M. S., Prokof'eva, T. V., Lysak, L. V. and Rakhleeva, A. A. (2016): Soil organic matter in the Moscow State University botanical garden on the Vorob'evy Hills. Eurasian Soil Science, 49(9): 1013-1025. doi: 10.1134/S106422931609012X

Schindelbeck, R. R., van Es, H. M., Abawi, G. S., Wolfe, D. W., Whitlow, T. L., Gugino, B. K., Idowu, O. J. and Moebius-Clune, B. N. (2008): Comprehensive assessment of soil quality for landscape and urban management. Landscape and Urban Planning, 88(2-4): 73-80. doi: 10.1016/j.landurbplan.2008.08.006

SchmidT, D. J. E. (2016): The ecology of urbanization: A study of soil microbial community response. Doctor of Sciences (Biol) Dissertation, University of Maryland, College Park, Maryland, 215 p. doi: 10.13016/M26V4N

Seifert, K., Morgan-Jones, G., Gams, W. and Kendrick, B. (2011): The genera of Hyphomycetes. Utrecht: CBS, Reus, Spain, 997 p.

SeIfERT, K.A., GAms, W. (2011): The genera of Hyphomycetes-2011 update. Persoonia: Molecular Phylogeny and Evolution of Fungi, 27: 119-129. doi: 10.3767/003158511X617435

Sharipova, M. Yu., Dubovik, I. Ye. (2004): Complex studing of algaflora of Ufa. Vestnik Bashkirskogo universiteta [Bulletin of the Bashkir University], 9(4): 45-50. (In Russian). 
Sharkova, S. Yu., Parfenova, Ye. A. and Polyanskova, Ye. A. (2011): Bioindication of the urban environment by the state of the microbial complex of soils. Ekologiya i promyshlennost Rossii [Ecology and industry of Russia], 11: 44-47. (In Russian).

SheA, K., Roxburgh, S. H. and Rauschert, E. S. J. (2004): Moving from pattern to process: coexistence mechanisms under intermediate disturbance regimes. Ecology Letters, 7(6): 491508. doi: 10.1111/j.1461-0248.2004.00600.x

Sherman, C., Unc, A., Doniger, T., Ehrlich, R. and Steinberger, Y. (2019): The effect of human trampling activity on a soil microbial community at the Oulanka Natural Reserve, Finland. Applied Soil Ecology, 135(14): 104-112. doi: 10.1016/j.apsoil.2018.11.013

ShtinA, E. A. (1990): Soil algae as ecological indicators. Botanicheskiy zhurnal [Botanical journal], 75(1): 441-452. (In Russian).

ShtinA, E. A. Gollerbakh, M. M. (1976): Ecology of soil algae. Nauka Publ., Moscow, Russia, 143 p. (In Russian).

Shumilova, L. P., Kuimova, N. G. (2013): The study of microbial association in city soils by the gas chromatography-mass spectrometry method. Byulleten fiziologii $i$ patologii dykhaniya [Respiratory Physiology and Pathology Bulletin], 50: 121-125. (In Russian).

Škaloud, P., Rindi, F., Boedeker, C. and Leliaert, F. (2018): Freshwater Flora of Central Europe. Chlorophyta: Ulvophyceae (Süßwasserflora von Mitteleuropa, Bd. 13: Chlorophyta: Ulvophyceae). Springer-Verlag, 289 p. doi: 10.1007/978-3-662-55495-1

Steffan, J. J., BreviK, E. C., Burgess, L. C. and CerdÀ, A. (2018): The effect of soil on human health: an overview. European Journal of Soil Science, 69(1):159-171. doi: 10.1111/ejss. 12451

Stepanov, A. L., Manucharova, N. A., Smagin, A. V., Kurbatova, A. S., Myagkova, A. D., and BASHKIN, V. N. (2005): Characterization of the biological activity of the microbial complex in urban soils. Eurasian Soil Science, 38(8): 864-869.

TRIFonova, T. A., ZaBeLINA, O. N. (2017): Changes in the biological activity of heavy metal- and oil-polluted soils in urban recreation territories. Eurasian Soil Science, 50(4): 483-490. doi: $10.1134 /$ S1064229317040147

Trukhnitskaya, S. M., Chizhevskaya, M. V. (2008): Algoflora in the recreation areas of the Krasnoyarsk urboecosystem. Krasnoyarsk State Agrarian University Publ., Krasnoyarsk, Russia, 139 p. (In Russian).

Trzciński, P., Sas-Paszt, L. M., Gıuszek, S., Przybye, M. and Derkowska, E. (2018): Effect of organic cultivation on the occurrence of beneficial groups of microorganisms in the rhizosphere soil of vegetable crops. Journal of Horticultural Research, 26(2): 15-24. doi: 10.2478/johr2018-0012

Turchanovskaya, N. S., Bogdanova, O. Yu. (2011): Microbiological study of the soil of Murmansk city. Uspekhi sovremennogo yestestvoznaniya [The Successes of Modern Natural Science], 8: 72. (In Russian).

VASEnev, V., Kuzyakov, Y. (2018): Urban soils as hot spots of anthropogenic carbon accumulation: Review of stocks, mechanisms and driving factors. Land Degradation \& Development, 29(6): 1607-1622. doi: 10.1002/ldr.2944

Vermeire, M. L., Bonneville, S., Stenuit, B., Delvaux, B. and Cornélis, J. T. (2019): Is microbial reduction of $\mathrm{Fe}$ (III) in podzolic soils influencing $\mathrm{C}$ release? Geoderma, 340(1): 1-10. doi: 10.1016/j.geoderma.2018.12.045

Wang, H., Marshall, C. W., Cheng, M., Xu, H., Li, H., Yang, X. and Zheng, T. (2017): Changes in land use driven by urbanization impact nitrogen cycling and the microbial community composition in soils. Scientific Reports, 7: 44049. doi: 10.1038/srep44049

Wille, L., Messmer, M. M., Studer, B. and Hohmann, P. (2019): Insights to plant-microbe interactions provide opportunities to improve resistance breeding against root diseases in grain legumes. Plant, Cell \& Environment, 42(1): 20-40. doi: 10.1111/pce.13214

YAN, B., Li, J., XIAO, N., QI, Y., FU, G., LIU, G. and QIAO, M. (2016): Urban-development-induced changes in the diversity and composition of the soil bacterial community in Beijing. Scientific Reports, 6: 38811. doi: 10.1038/srep38811 
Ye, G., Lin, Y., LuO, J., Di, H. J., LindSeY, S., LiU, D., FAN, J. and Ding, W. (2020): Responses of soil fungal diversity and community composition to long-term fertilization: Field experiment in an acidic Ultisol and literature synthesis. Applied Soil Ecology, 145: 103305. doi: 10.1016/ j.apsoil.2019.06.008

ZabeLINA, O. N. (2014): Enzymatic activity of recreational landscapes soil in urban areas. Sovremennyye problemy nauki i obrazovaniya [Modern Problems of Science and Education], 2: 493-501. (In Russian).

ZaYdelman, F. R. (2016): The role of gley formation in soil formation and degradation. Vestnik Rossiyskoy akademii nauk [Bulletin of the Russian Academy of Sciences], 86(4): 342-342. (In Russian). doi: 10.7868/S086958731604023X

ZvyagintSEv, D. G. (1991): Methods of soil microbiology and biochemistry. Moscow State University Publ., Moscow, Russia, 304 p. (In Russian).

\section{Web sources / Other sources}

[1] Weather online.

https://www.weatheronline.co.uk/ (Accessed 20.12.2020).

[2] Climatic data of cities worldwide (2020).

https://ru.climate-data.org/ (Accessed 20.12.2020).

[3] IUSS Working Group WRB (2015): World Reference Base for Soil Resources 2014, update 2015. International soil classification system for naming soils and creating legends for soil maps. World Soil Resources Reports, No. 106. FAO, Rome, Italy, 203 p.

[4] Index Fungorum (2021): A nomenclatural database. CABI Bioscience Databases. http://www.indexfungorum.org. (Accessed 09.02.2021).

[5] Guiry, M. D., Guiry, G. M. (2021): AlgaeBase. World-wide electronic publication. National University of Ireland, Galway. http://www.algaebase.org. (Accessed 15.01.2021). 